\title{
Effects of Multiple Dimensions of Intangible Distance on Agro-food Exports: Evidence from China
}

\author{
Xinran Liu ${ }^{1}$ \\ ${ }^{1}$ Department of International Trade, Qilu University of Technology (Shandong Academy of Sciences), Jinan, \\ China \\ Correspondence: Xinran Liu, Department of International Trade, Qilu University of Technology (Shandong \\ Academy of Sciences), Jinan, China. Tel: 86-137-9101-8061. E-mail: xz10030@ auburn.edu
}

Received: November 4, 2019

Accepted: November 26, 2019

Online Published: November 30, 2019

doi:10.5539/ijef.v11n12p75

URL: https://doi.org/10.5539/ijef.v11n12p75

\begin{abstract}
Intangible distance may play a role as both trade barriers and competitive advantages in cross-border trade. Moreover, for agro-food products, intangible distance reflects the discrepancy between eating habits of the importing and exporting countries, and thus affects agro-food trade also as "eating-habit distance". This paper investigates the effects of four dimensions of intangible distance on China's agro-food exports, namely, cultural distance, institutional distance, distance in education, and distance in industrial development. A panel data of 78 countries covering the period 2002-2016 is used, and an extended gravity model is employed. We control for the effects of quality or level of institution, education, and industrial development of China and its trading partners to distinguish the "quality effects" from "distance effects" and to test the robustness of the results. To explore the (possible) different effects of intangible distance on different categories of agro-food products, we consider not only the total agro-food exports, but also the individual samples of the four agro-food categories classified according to the Harmonized System codes. We find that all these dimensions of intangible distance influence China's agro-food exports significantly, at least for certain categories of agro-food products. Distance in institution, education, and industrial development function as measures of trade costs, whereas cultural distance functions more like a reflection of competitive advantage. Furthermore, when the distance in institution, education or industrial development increases in favor of the importing countries, the negative effects of intangible distance are partly neutralized by the importers' improved level of institution, education or industrialization.
\end{abstract}

Keywords: agro-food trade, intangible distance, cultural distance, institutional distance, distance in education, distance in industrial development

\section{Introduction}

As a basic variable in the gravity model, geographical distance is considered closely related to trade costs, and much of the literature has found a negative impact of the geographical distance between trading partners on exports and imports (e.g. Egger, 2000; Disdier \& Head, 2008; Yotov, 2012). In recent years, some other dimensions of distance (e.g. distance in culture, language, religion, institution, education and industrial development) have also been assumed to increase the difficulty of exchanging information among market participants, and are thus considered as measures of transaction costs. Therefore, in the last few decades, these multiple types of distance have drawn growing attention in the literature.

The distance between languages, cultures, religions, and between levels of institution, education, or industrial development is often referred to as the "intangible distance" (Anderson \& van Wincoop, 2004; Lankhuizen, De Graaff, \& de Groot, 2015; Liu, Lu, \& Wang, 2018). A large number of studies have investigated the role of intangible distance in imports and exports. For example, a common language (even a common acquired language) between exporting and importing countries is found to be able to stimulate cross-border trade (Egger \& Lassmann, 2015; Egger \& Toubal, 2018), and sharing a religion may either promote or hamper international trade (Lewer \& Van den Berg, 2007). However, few studies have paid attention on the agro-food industry. Agro-food trade is closely associated with eating habits (Bureau, Marette, \& Schiavina, 2000; Alfnes, 2004), which are determined, to some degree, by a country's culture, education and industrial development (e.g. Papadaki \& Scott, 2002; Shinagawa et al., 2009; Yu, King, \& Yoon, 2010; Alnohair, 2014). Therefore, apart from 
being a measure of costs that directly related to transactions, the intangible distance may affect the agro-food trade by influencing dietary habits, and thus, intangible distance may play an especially important role in trading food and agricultural products.

On the other hand, although the several dimensions of intangible distance can be considered measures of trade costs, and thus work as trade barriers, they also reflect comparative advantages in cultures, institutions, human resources or labor costs (Belloc, 2006; Levchenko, 2007; Lankhuizen, de Groot, \& Linders, 2011). Such effects may vary across different industries. Is it possible that in agro-food industry, the intangible distance work more like a measure of comparative advantage, rather than a measure of trade barriers?

This study aims to contribute to the discussion on the "intangible distance - trade" relationship with a focus on China's agro-food industry by investigating the impacts of four dimensions of intangible distance on China's agro-food exports, namely, cultural distance and distance in institution, education and industrial development. To explore the (possible) different effects of intangible distance on different categories of agro-food products, we consider not only the total agro-food exports, but also the individual samples of the four agro-food categories classified according to the Harmonized System codes (Note 1).

Using an extended gravity model and a penal data of 78 countries covering 2002-2016, we find that, for the total agro-food exports, institutional distance is the only dimension of intangible distance that has a significant (negative) effect on China's exports. However, in the four individual samples, distance in educational and industrial levels significantly lower agro-food exports of certain categories, whereas the effect of cultural distance is in the opposite direction. The results are proved to be robust by including the country- and year-fixed effects in the regression, and by adding the levels of institution, education and industrial development into the model.

The outline of this paper is as follows: Section 2 reviews the related literature. Section 3 presents the model and describes the data used to estimate the effects of the aforementioned four dimensions of distance on China's agro-food exports. Section 4 discusses the estimation results, and Section 5 concludes.

\section{A Brief Literature Review on the Multiple Dimensions of Intangible Distance}

Cultural distance is the most frequently mentioned intangible distance in the literature. It measures the differences between different cultures (Clark \& Pugh, 2001; Shenkar, 2001). First introduced by Beckerman (1956), this concept became popular in the literature in the 1970s and 1980s (Johanson \& Wiedersheim-Paul, 1975; Johanson \& Vahlne, 1977; Hofstede, 1980; Kogut \& Singh, 1988). It reflects the difference in the modes of communicating and understanding information, and, hence, influences trade cost. Cultural distance is expected to be relatively smaller between two countries that share the same language and same border. However, the measure of cultural distance can be made much more comprehensive, to include several dimensions of cultural values and norms. Many frameworks have been developed to measure cultures, the most popular of which by Hofstede $(1980,2010)$ and Schwartz (1995). Current empirical studies provide mixed results on the influence of cultural distance on trade flows, due to the different samples or model specifications used (e.g., Linders, Slangen, de Groot, \& Beugelsdijk, 2005; Tadesse \& White, 2010; Lankhuizen et al., 2015; Liu et al., 2018). As regards the relationship between cultural distance and the consumption of agro-food products, as mentioned above, dietary habits are closely related to culture. On the one hand, cultural distance may work as a trade barrier as it reflects the differences between eating habits of the exporting country and the importing country. On the other hand, it may make the agro-food products of a country more attractive to foreign consumers as it triggers curiosity and provides novelty. However, the influence of cultural distance on the trade of agro-food products has long been neglected by the literature.

A concept related to cultural distance is psychic distance. In early publications, the two concepts are very often used interchangeably (Benito \& Gripsrud, 1992; Lee, 1998). Then, an increasing number of studies began to distinguish one from the other, and the concept of psychic distance is currently considered to cover a broader range of dimensions (Dow \& Karunaratna, 2006). Different studies have different definitions for psychic distance; however, most of them involve distance in institution, education and industrial development.

Quality of institution reflects the basic statutory and social rules for production, exchange, and distribution. A higher institutional level implies a lower level of corruption, a higher level of legal system quality and of political stability, and, thus, a relatively level playing field. An importing and/or exporting country with a higher level of institution can contribute to greater transparency, increase the trust between trading partners, and lower trade barriers, and is thus found to be related to a larger volume of agricultural trade (Levchenko, 2007; Bojnec \& Ferto, 2014; Alvarez, 2018). Many studies focus on how the discrepancy between countries' institutional levels affects communication costs and bilateral trade (e.g., Dow \& Karunaratna, 2006; Lankhuizen et al., 2011; 
Lankhuizen et al., 2015). Functioning similarly to cultural distance, institutional distance or similarities is found out to be an important factor influencing bilateral trade in many sectors. Nevertheless, in the literature, barely any attention has been paid to such impacts on trade of agro-food products.

Similarly, as components of psychic distance, distance in education and industrial development also affect the communication costs. Moreover, similar to cultural distance, distance in education and industrial development may be associated with dietary habits as well. For instance, people with a higher level of education are likely to consume more low-fat foods, and people in countries with a higher level of industrial development are likely to prefer more processed food. Therefore, distance in education and industrial development can influence agro-food exports not only by affecting the transaction costs, but also by impacting dietary habits (Yu et al., 2010; Alnohair, 2014). Furthermore, they reflect the differences in human capital resources or labor costs and thus imply a comparative advantage that encourages bilateral trade (Dow \& Karunaratna, 2006; Palmero, Herrera, \& Fuente Sabaté, 2013). As a result, the magnitude and direction of the effects of distance in education and industrial development on agro-food trade are determined by the relative magnitude of the two effects.

Table 1 summarizes representative studies about effects of intangible distance on cross-border trade or FDI with country-level data. It is shown that most of them focus on distance in culture and institution and results are mixed. Fewer empirical studies involve distance in education and industrial development and these two dimensions are more frequently mentioned as indicators of psychic and studied using non-empirical methods.

Table 1. Summary of the existing empirical studies on the effect of intangible distance on trade or FDI

\begin{tabular}{|c|c|c|c|c|}
\hline \multirow{2}{*}{\multicolumn{5}{|c|}{ Distance in Culture }} \\
\hline & & & & \\
\hline \multicolumn{5}{|l|}{ Linders, Slangen, de Groot, \& } \\
\hline Beugelsdijk (2005) & 92 Countries & 1999 & Trade Flows & Positive \\
\hline Dow \& Karunaratna (2006) & 38 Coutries & 1993-1998 & Trade Flows & Insignificant \\
\hline Tadesse \& White (2010) & US and its 75 Trading Partners & 2006 & Trade Flows & Negative \\
\hline Dow \& Ferencikova (2010) & Slovakia and its 87 OFDI Destinations & $1990-2006$ & OFDI & Insignificant \\
\hline Lankhuizen et al. (2011) & OECD Countries and Trade Partners & 1984-1990 & Exports and OFDI & I Negative \\
\hline Blomkvist \& Drogendijk (2013) & China and its OFDI Destinations & 2003-2009 & OFDI & Negative \\
\hline Lankhuizen et al. (2015) & 72 Countries & 2000 & Trade Flows & Negative \\
\hline Liu, Lu, \& Wang (2018) & China and 99 Trading Partners & $2002-2016$ & Trade Flows & Negative \\
\hline \multicolumn{5}{|l|}{ Distance in Institution } \\
\hline \multicolumn{5}{|l|}{ Linders, Slangen, de Groot, \& } \\
\hline Beugelsdijk (2005) & 92 Countries & 1999 & Trade Flows & Negative \\
\hline Lankhuizen et al. (2011) & OECD Countries and Trade Partners & 1984-1990 & Exports and OFDI & I Positive \\
\hline Lankhuizen et al. (2015) & 72 Countries & 2000 & Trade Flows & Negative \\
\hline Liu, Lu, \& Wang (2018) & China and 99 Trading Partners & $2002-2016$ & Trade Flows & Negative \\
\hline Li, Luo, \& Vita (2018) & China and 150 OFDI Destinations & 2003-2015 & OFDI & Negative \\
\hline Álvarez et al. (2018) & 186 Countries & $1996-2012$ & Trade Flows & Positive \\
\hline \multicolumn{5}{|l|}{ Distance in Education } \\
\hline Dow \& Karunaratna (2006) & 38 Coutries & 1993-1998 & Trade Flows & Negative \\
\hline Blomkvist \& Drogendijk (2013) & China and its OFDI Destinations & 2003-2009 & OFDI & Insignificant \\
\hline \multicolumn{5}{|c|}{ Distance in Industrial Development } \\
\hline Dow \& Karunaratna (2006) & 38 Coutries & 1993-1998 & Trade Flows & Negative \\
\hline Blomkvist \& Drogendijk (2013) & China and its OFDI Destinations & 2003-2009 & OFDI & Insignificant \\
\hline \multicolumn{5}{|c|}{ Psychic Distance as a Single Variable } \\
\hline Dow \& Karunaratna (2006) & 38 Coutries & 1993-1998 & Trade Flows & Negative \\
\hline Dow \& Ferencikova (2010) & Slovakia and its 87 OFDI Destinations & s 1990-2006 & OFDI & Negative \\
\hline Blomkvist \& Drogendijk (2013) & China and its OFDI Destinations & 2003-2009 & OFDI & Negative \\
\hline
\end{tabular}

\section{Model and Data}

\subsection{The Gravity Model for Agro-food Exports}

The gravity model is the workhorse model for studying cross-region flows, including flows of information, trade, investment, and migration (e.g. Anderson \& van Wincoop, 2003; Tadesse \& White, 2008). In the basic gravity 
model, bilateral trade between countries $i$ and $j$ is usually found to be positively related to the size of the two economies and negatively related to the trade costs between them. The relationship of country size, trade barriers, and trade flows can be specified as follows:

$$
X_{i j}=\alpha_{0} Y_{i}^{\alpha_{1}} Y_{j}^{\alpha_{2}} D_{i j}^{\alpha_{3}} \varepsilon_{i j}
$$

where $X_{i j}$ denotes the exports from country $i$ to country $j . Y_{i}$ and $Y_{j}$ denote factors that reflect the size of the origin and destination markets (e.g. GDP and population), respectively. A larger country is expected to have a greater demand for imports and more production potential for exports. $D_{i j}$ denotes the trade barriers between the exporting and importing countries, among which geographical distance is the most widely used variable. Moreover, Ghemawat (2001) suggests that "distance" can be measured not only in terms of geography, but also in terms of culture, administration, and economic development, and, thus, common language, common border, and existing free trade agreements between trading partners are also commonly used variables to measure the trade costs between countries in the literature. In the present study, we consider four more measures of "distance" in the model - the multiple dimensions of intangible distance mentioned in the previous sections. $\varepsilon_{i j}$ denotes the error term. Adding a time dimension to the model and taking the logarithm of equation (1), the basic gravity model can be written as follows:

$$
\begin{gathered}
\ln X_{c i t}=\alpha_{0}+\beta_{1} \operatorname{lnGDP}_{c t}+\beta_{2} \operatorname{lnGDP}_{i t}+\beta_{3} \text { ComLang }_{c i}+\beta_{4} \text { Contig }_{c i}+\beta_{5} \operatorname{lnDIST}_{c i} \\
+\beta_{7} \text { FT }_{\text {cit }}+\gamma_{e} \text { IntangDIST }_{c i e t}+u_{i t}
\end{gathered}
$$

where $X_{c i t}$ denotes the exports of agro-food products from China to country $i$ in year $t . G D P_{c t}$ and $G D P_{i t}$ denote the Gross Domestic Product of China and country $i$ in year $t$, respectively. ComLang ${ }_{c i}$ and Contig $g_{c i}$ are the language dummy and the common border dummy, respectively. $D I S T_{c i}$ denotes the geographical distance between China and country i. FTA $A_{c i t}$ is a dummy variable that represents whether there is a free trade

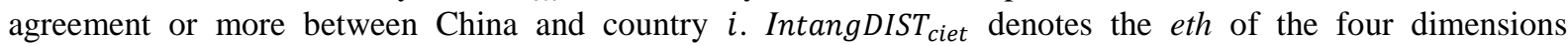
measuring the intangible distance between China and country $i$ in year $t$ : cultural distance, institutional distance, distance in education, and distance in industrial development. To mitigate the potential problem of reverse causality, all the intangible distance measures are lagged by one year. To avoid the problem of multicollinearity, only one variable of intangible distance is included in each regression.

\subsection{Data}

The sample consists of 78 countries (presented in Table 2) and covers the period from 2002 to 2016. Data on agro-food exports of China and its trading partners are from the UN Comtrade database and cover HS codes 01-24. Figure 1 shows China's agro-food exports to the world during 2002-2016, including both the total agro-food exports and the exports of the four categories classified according to the Harmonized System codes. Among the four categories, the exports of food, beverages and tobaccos account for the largest proportion. Although exports of all the categories are in an uptrend, they are not increasing at identical speeds. Therefore, in the present paper, we consider not only the total exports of the agro-food sector, but also four individual samples of the four categories, and to explore how the intangible distance works in different categories.

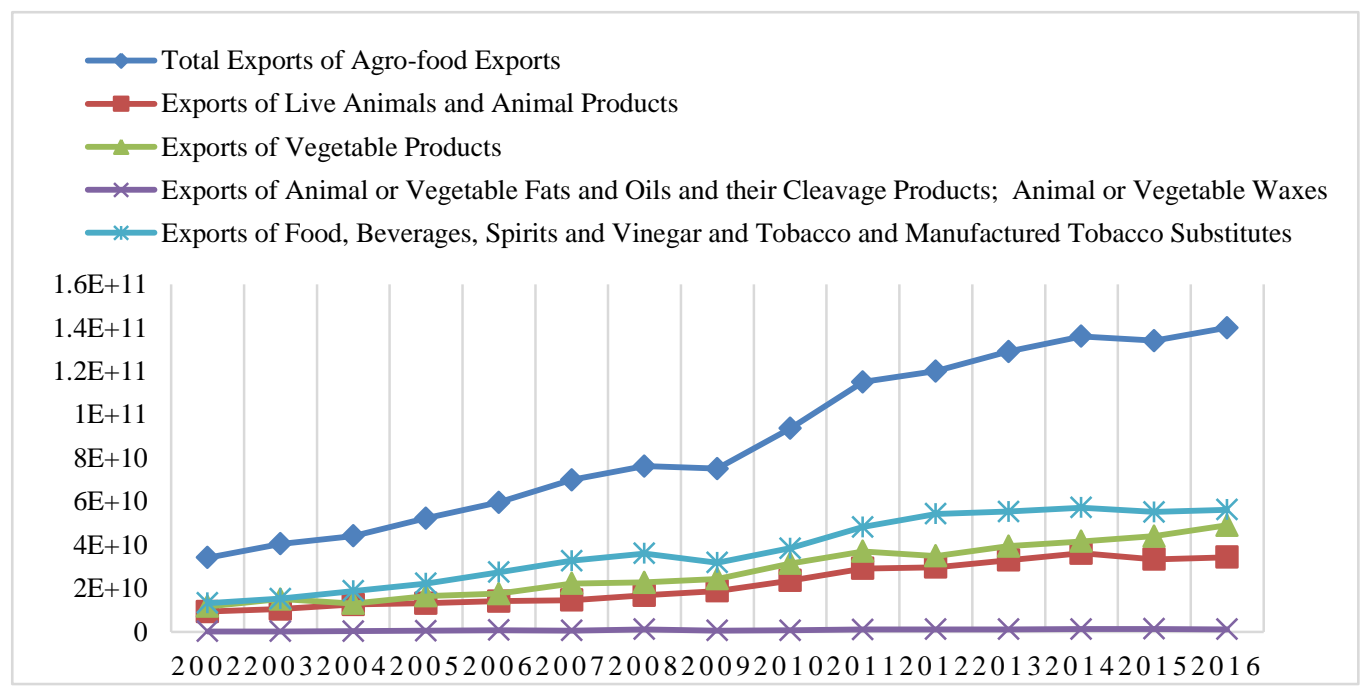

Figure 1. China's exports of agro-food products during 2002-2016 (US Dollar) 
Table 2. Country list of the sample

\begin{tabular}{llll}
\hline Albania & Finland & Lithuania & Romania \\
Argentina & France & Luxembourg & Russian Federation \\
Australia & United Kingdom & Latvia & Sudan \\
Austria & Ghana & Morocco & El Salvador \\
Belgium & Greece & Mexico & Serbia \\
Bangladesh & Hong Kong & Malta & Slovakia \\
Bulgaria & Croatia & Mozambique & Slovenia \\
Belarus & Hungary & Mauritius & Sweden \\
Brazil & India & Malaysia & Thailand \\
Switzerland & Indonesia & Netherlands & Tunisia \\
Chile & Iceland & Norway & Turkey \\
Colombia & Iran & Nepal & Tanzania \\
Czech Republic & Ireland & New Zealand & Ukraine \\
Germany & Italy & Oman & Uruguay \\
Denmark & Jordan & Pakistan & United States of America \\
Egypt & Japan & Peru & Venezuela \\
Eritrea & Kenya & The Philippines & Yemen \\
Spain & Kyrgyzstan & Poland & South Africa \\
Estonia & South Korea & Portugal & \\
Ethiopia & Lebanon & Qatar & \\
\hline
\end{tabular}

Data on the GDP of China and its trading partners are obtained from the World Development Indicator database. The CEPII database provides data on common language, common border, and geographical distance, among which geographical distance measures the distance between the capitals of China and each of trading partners. There are two indicators of common language in the CEPII database: whether the two countries have the same official language, and whether there is a common language spoken by at least $9 \%$ of the population of each country. For China and its trading partners, the values of these two measures are the same, and we use the common official language as the language dummy.

In addition to common language, we use Hofstede's (2010) measure of national norms and values to compute the cultural distance between China and its trading partners. The framework covers indicators for six dimensions: masculinity versus femininity, uncertainty avoidance, individualism versus collectivism, power distance, long-term orientation, and indulgence.

Data on institutional quality are from World Governance Indicators, which consists of six indicators that reflect the quality of governance of over 200 countries. These indicators are: control of corruption, government effectiveness, regulatory quality, rule of law, voice, and accountability. Then, the data were used to compute the institutional distance between China and the importing countries.

Following previous studies (Sousa \& Bradley, 2006; Dow \& Karunaratna, 2006; Hakanson \& Ambos, 2010) and considering the availability of data, we chose three indicators to compute distance in education: school life expectancy, enrolment in tertiary education per 100,000 inhabitants, and expenditure on education as a percentage of GDP. In the same way, five indicators were selected to compute the distance in industrial development: GDP per capita, energy consumption per capita, internet users per 100 people, manufacturing as a percentage of GDP, and percentage of urban population. Data on these indicators for education and industrial development are from World Bank Statistics.

Since most of the distance variables are measured by more than one indicator, it is necessary to reduce the dimensionality to make the values of the variables available for the regression. Following previous studies (Dow \& Karunaratna, 2006; Kogut \& Singh, 1988), different methods are utilized to reduce the dimensionality for each distance variable: First, principal component analysis is used for distance in institution, education and industrial development. If there is still more than one dimension after reducing the dimensionality of the individual variables, the weighted average of the components is calculated, using the proportion of variance as a weight. Second, we use a modified Kogut-Singh's index to reduce the dimensionality of cultural distance, which takes the time factor into consideration. The time-varying Kogut-Singh's index is:

$$
\text { IntangDIST }_{c i}=(1 / n) \sum_{k=1}^{n}\left(I_{i, k}-I_{c, k}\right)^{2} / V_{k}+1 / \text { Year }_{c i}
$$

where $n$ is the number of indicators of cultural distance, $I_{i, k}$ is the value of the $k$ th indicator of country $i$, and 
$V_{k}$ is the variance of the $k$ th indicator for all the countries in the sample. $Y_{e a r} r_{c i}$ is the number of years since China and country $i$ have established diplomatic ties.

Although the countries in our sample are all listed in the Hofstede six-dimensional culture database, there are still some missing values for certain countries in some indicators. To address, in this study, before computing the cultural distance, the missing values in culture values were imputed using the values of similar areas (e.g. the values of Hofstede's indicator of long-term versus short-term for Ethiopia were imputed with the values of East Africa). Moreover, to deal with the zero values in the data of agro-food exports, $\ln \left(X_{c i t}+1\right)$ is used as the dependent variable, instead of $\ln X_{c i t}$. The summary statistics and correlation matrix are shown in Table 3 and Table 4, respectively.

Table 3. Summary statistics

\begin{tabular}{|c|c|c|c|c|c|c|}
\hline Variable & Description & Obs & Mean & Std. Dev. & Min & Max \\
\hline $\ln \left(X_{c i t}+1\right)$ & Agro-food exports $+1(\ln )$ & 1092 & 17.92 & 2.32 & 0 & 23.2 \\
\hline $\ln G D P_{i t}$ & GDP of country $i(\ln )$ & 1092 & 26.23 & 1.6 & 22.37 & 30.58 \\
\hline $\ln G D P_{c t}$ & GDP of China & 1092 & 30.05 & 0.448 & 29.26 & 30.68 \\
\hline Contig $_{c i}$ & Common border dummy & 1092 & 0.077 & 0.267 & 0 & 1 \\
\hline ComLang $_{c i}$ & Language dummy & 1092 & 0.026 & 0.158 & 0 & 1 \\
\hline $\ln D I S T_{c i}$ & Geological distance (ln) & 1092 & 8.9 & 0.506 & 6.86 & 9.87 \\
\hline$F T A_{c i t}$ & FTA dummy & 1092 & 0.061 & 0.24 & 0 & 1 \\
\hline CulDIST $_{\text {cit }}$ & Distance in culture (lag) & 1092 & 2.97 & 1.25 & 0.662 & 5.95 \\
\hline InstiDIST $_{\text {cit }}$ & Distance in institution (lag) & 1092 & 2.1 & 1.37 & 0.001 & 5.01 \\
\hline$E d u D I S T_{\text {cit }}$ & Distance in education (lag) & 989 & 0.511 & 0.389 & 0 & 2.38 \\
\hline IndusDIST $_{c i 1}$ & Distance in industrial development (lag) & 936 & 0.874 & 0.732 & 0 & 3.98 \\
\hline InstiLEVEl $_{i t}$ & Quality/Level of institution of country $i$ (lag) & 1092 & 0.342 & 0.945 & -1.62 & 1.97 \\
\hline IndusLEVEl & Quality/Level of industrial development of country $i$ (lag) & 1092 & -0.124 & 0.606 & -1.27 & 1.25 \\
\hline$E d u L E V E l_{i t}$ & Quality/Level of education of country $i$ (lag) & 989 & 0.394 & 1.13 & -3.5 & 2.82 \\
\hline InstiLEVEl $_{c t}$ & Quality/Level of institution of China (lag) & 1092 & -0.127 & 1.25 & -2.24 & 1.56 \\
\hline IndusLEVEl & Quality/Level of industrial development of China (lag) & 899 & 0.286 & 1.08 & -1.77 & 4.16 \\
\hline$E d u L E V E l_{c t}$ & Quality/Level of education of China (lag) & 1092 & -0.286 & 1.94 & -2.73 & 3.33 \\
\hline
\end{tabular}

Table 4. Correlation matrix ( $\mathrm{N}=1092)$

\begin{tabular}{|c|c|c|c|c|c|c|c|c|c|c|c|c|c|c|c|c|c|}
\hline & (1) & (2) & (3) & (4) & (5) & (6) & (7) & (8) & (9) & (10) & (11) & (12) & (13) & (14) & (15) & (16) & (17) \\
\hline (1) & 1 & & & & & & & & & & & & & & & & \\
\hline (2) & 0.739 & 1 & & & & & & & & & & & & & & & \\
\hline (3) & 0.240 & 0.139 & 1 & & & & & & & & & & & & & & \\
\hline (4) & 0.180 & 0.068 & 0 & 1 & & & & & & & & & & & & & \\
\hline (5) & 0.259 & 0.055 & 0 & 0.258 & 1 & & & & & & & & & & & & \\
\hline (6) & -0.344 & -0.133 & 0 & -0.420 & -0.293 & 1 & & & & & & & & & & & \\
\hline (7) & 0.171 & 0.110 & 0.211 & 0.069 & 0.103 & -0.033 & 1 & & & & & & & & & & \\
\hline (8) & -0.044 & 0.010 & -0.007 & -0.264 & -0.132 & 0.423 & -0.029 & 1 & & & & & & & & & \\
\hline (9) & 0.018 & 0.025 & -0.018 & -0.018 & 0.029 & -0.074 & 0.011 & 0.493 & 1 & & & & & & & & \\
\hline (10) & -0.138 & -0.118 & -0.202 & -0.003 & -0.100 & -0.012 & 0.039 & 0.296 & 0.507 & 1 & & & & & & & \\
\hline (11) & -0.091 & -0.070 & 0.048 & 0.018 & -0.043 & -0.187 & -0.033 & 0.216 & 0.657 & 0.486 & 1 & & & & & & \\
\hline (12) & 0.113 & 0.124 & -0.013 & -0.222 & 0.095 & 0.036 & 0.002 & 0.565 & 0.602 & 0.118 & 0.382 & 1 & & & & & \\
\hline (13) & 0.114 & 0.082 & 0.628 & 0 & 0 & 0 & 0.158 & -0.003 & -0.017 & -0.111 & 0.0001 & -0.003 & 1 & & & & \\
\hline (14) & 0.078 & 0.091 & 0.172 & -0.307 & -0.026 & 0.173 & -0.074 & 0.665 & 0.498 & 0.340 & 0.245 & 0.704 & 0.101 & 1 & & & \\
\hline (15) & 0.241 & 0.137 & 0.992 & 0 & 0 & 0 & 0.207 & -0.007 & -0.018 & -0.211 & 0.048 & -0.013 & 0.655 & 0.17 & 1 & & \\
\hline (16) & 0.116 & 0.216 & 0.165 & -0.247 & 0.052 & -0.035 & -0.024 & 0.554 & 0.631 & 0.207 & 0.493 & 0.818 & 0.058 & 0.723 & 0.163 & 1 & \\
\hline (17) & 0.215 & 0.131 & 0.963 & 0 & 0 & 0 & 0.217 & -0.006 & -0.018 & -0.182 & 0.036 & -0.011 & 0.767 & 0.173 & 0.947 & 0.157 & 1 \\
\hline
\end{tabular}

Note. (1) Agro-food exports+1 (ln); (2) GDP of country $i$ (ln); (3) GDP of China; (4) Common border dummy; (5) Language dummy; (6) Geological distance (ln); (7) FTA dummy; (8) Cultural distance (lag); (9) Institutional distance (lag); (10) Distance in education (lag); (11) Distance in industrial development (lag); (12) Quality/level of institution of country $i$ (lag); (13) Quality/level of institution of China (lag); (14) Quality/level of education of country $i$ (lag); (15) Quality/level of education of China (lag); (16) Quality/level of industrial development of country $i$ (lag); (17) Quality/level of industrial development of China (lag) 
As advised by Dow and Karunaratna (2006), all the dimensions of intangible distance are measured in absolute values. This means that a country with a distance from China can be either at a higher or a lower side. However, as shown in Figure 2, the developed Northern and Western European countries have the most different culture values, institutional, industrial and educational levels from China, suggesting that a larger intangible distance may imply a higher level of institution, education or industrial development of China's trading partners (also shown in Table 4). This problem is discussed in detail in section 4.3

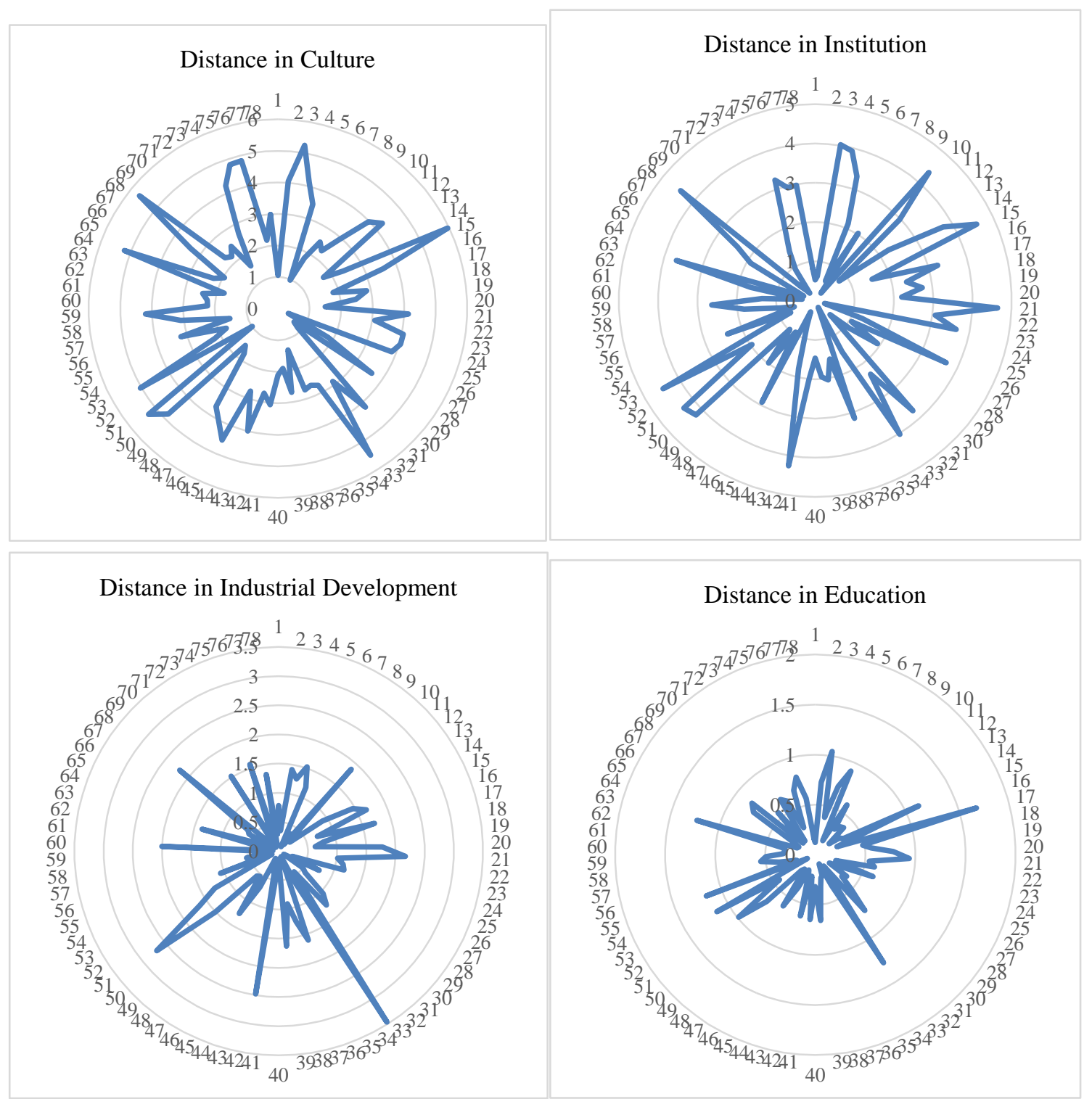

Figure 2. The mean value of distance in culture, institution, industrial development and education between china and the importing countries

Note. 1- Albania; 2- Argentina; 3- Australia; 4- Austria; 5- Belgium; 6- Bangladesh; 7- Bulgaria; 8- Belarus; 9- Brazil; 10- Switzerland; 11Chile; 12- Colombia; 13- Czech Republic; 14- Germany; 15- Denmark; 16- Egypt; 17- Eritrea; 18- Spain; 19- Estonia; 20- Ethiopia; 21Finland; 22- France; 23- United Kingdom; 24- Ghana; 25- Greece; 26- Hong Kong; 34- Italy; 35- Jordan; 36- Japan; 37- Kenya; 38Kyrgyzstan; 39- Korea; 40- Lebanon; 41- Lithuania; 42- Luxembourg; 43- Latvia; 44- Morocco; 45- Mexico; 46- Malta; 47- Mozambique; 48- Mauritius; 49- Malaysia; 50- Netherlands; 51- Norway; 52- Nepal; 53- New Zealand; 54- Oman; 55- Pakistan; 56- Peru; 57- The Philippines; 65- Serbia; 66- Slovakia; 67- Slovenia; 68- Sweden; 69- Thailand; 70- Tunisia; 71- Turkey; 72- Tanzania; 73- Ukraine; 74Uruguay; 75- United States of America; 76- Venezuela; 77- Yemen; 78- South Africa. 


\section{Empirical Results}

This section presents the results from estimating the gravity equations of China's agro-food exports. Table 5 displays the regression results of the total agro-food exports. Column (1) reports the results of the basic gravity model and columns (2) - (5) report the results of regressions with distance in culture, institution, education, and industrial development, respectively. Moreover, to assess the robustness of the regression results, we also regress on the year- and country-fixed effects specifications, and the results are shown in columns (6) - (10). The fixed effects specifications are in line with the concerns about the country- and year- specific effects (Baier \& Bergstrand, 2002; Carrere, 2006). The disadvantage of using the fixed effects is that time-invariant, country-specific, and country-pair specific (Note 2) regressors cannot be included in the regression when the fixed effects are in the model.

\subsection{Basic Variables}

As shown in Table 5, China's agro-food exports are explained well by the basic variables. The directions and significance of most of the coefficients are consistent with the literature, the only exception being that the common border dummy is not significant, even at the $10 \%$ level. The agro-food exports increase with the GDP of both China and its exporting destinations, and in most of the results, China's GDP level has a larger impact on its agro-food exports than its trading partners' GDP does. The results for geographical distance do not support the argument of "death of distance," which states that due to the improvement of infrastructure and technology, geographical distance no longer plays an important role in determining international trade. In contrast, our results suggest that geographical distance is still an important approximation of trade costs. The coefficients are consistent with a great portion of the literature, which find that the geographical distance elasticity of trade to be approximately -1 (Overman, Redding, \& Venables, 2003; Chaney, 2018, etc.). A common language increases China's agro-food exports, implying that having the same official language indeed helps to reduce trade barriers. Moreover, free trade agreements increase agro-food exports significantly, suggesting that these agreements have realized their aims to lower the trade costs in the international agro-food market, at least to some extent. Comparing the results of the models with and without country- and year- specific fixed effects, we find that most of the results are robust across all the columns in Table 5.

\subsection{Effects of the Multiple Dimensions of Intangible Distance}

As reported in Table 5, among the four dimensions of intangible distance, institutional distance is the only one that affects China's total agro-food exports significantly. This means that the hypothesis proved in most of the literature, that a similar institutional level promotes exports is applicable to China's agro-food sector.

Can we conclude that other dimensions of intangible distance do not have any effect on China's agro-food exports? As mentioned before, we classify these exports into four categories, regressed the model on the four corresponding samples, and obtain the results shown in Table 6 (Note 3). We find that, for the sample of live animals and animal products (Sample No. 1) and beverages and tobaccos (Sample No. 4), cultural distance has a positive influence on China's exports. This seems at odds with some previous findings in the literature, which support the hypothesis that cultural distance hampers international trade. In fact, as aforementioned, apart from being a measure of "psychic distance", cultural distance also behaves as a measure of competitive advantage as it satisfies the curiosity of foreign consumers, and such effects may overweigh the effects of psychic distance.

Table 6. Estimation results for categorized agro-food exports

\begin{tabular}{|c|c|c|c|c|c|c|c|c|}
\hline Sample No. 1 & (1) & (2) & (3) & (4) & (5) & (6) & (7) & (8) \\
\hline \multirow[t]{2}{*}{$\mathrm{CulDIST}_{\text {cit }}$} & $0.395^{* *}$ & & & & $48.31 * * *$ & & & \\
\hline & $(0.166)$ & & & & (11.73) & & & \\
\hline \multirow[t]{2}{*}{ InstiDIST $_{\text {cit }}$} & & -0.121 & & & & $-0.552 * *$ & & \\
\hline & & $(0.122)$ & & & & $(0.248)$ & & \\
\hline \multirow[t]{2}{*}{ IndusDIST $T_{\text {cit }}$} & & & 0.210 & & & & $1.3213^{* * *}$ & \\
\hline & & & $(0.217)$ & & & & $(0.3353)$ & \\
\hline \multirow[t]{2}{*}{$E d u D I S T_{\text {cit }}$} & & & & -0.225 & & & & 0.448 \\
\hline & & & & $(0.298)$ & & & & (0.357) \\
\hline Observations & 897 & 937 & 843 & 865 & 897 & 937 & 843 & 865 \\
\hline Adjusted-R ${ }^{2}$ & 0.301 & 0.304 & 0.378 & 0.360 & 0.607 & 0.607 & 0.719 & 0.659 \\
\hline
\end{tabular}




\begin{tabular}{|c|c|c|c|c|c|c|c|c|}
\hline Sample No. 2 & & & & & & & & \\
\hline CulDIST $_{\text {cit }}$ & $\begin{array}{c}0.168 \\
(0.134)\end{array}$ & & & & $\begin{array}{c}29.75 \\
(19.258)\end{array}$ & & & \\
\hline InstiDIST $_{\text {cit }}$ & & $\begin{array}{c}-0.168^{* *} \\
(0.097)\end{array}$ & & & & $\begin{array}{l}-0.211^{*} \\
(0.135)\end{array}$ & & \\
\hline IndusDIST $_{\text {cit }}$ & & & $\begin{array}{l}-0.281^{*} \\
(0.168)\end{array}$ & & & & $\begin{array}{l}-0.103 \\
(0.288)\end{array}$ & \\
\hline$E d u D I S T_{c i t}$ & & & & $\begin{array}{c}-0.820 \text { *** } \\
(0.254)\end{array}$ & & & & $\begin{array}{c}-0.908 * * \\
* \\
(0.303)\end{array}$ \\
\hline Observations & 952 & 1,001 & 884 & 921 & 951 & 1,001 & 884 & 921 \\
\hline Adjusted- $\mathrm{R}^{2}$ & 0.354 & 0.373 & 0.514 & 0.441 & 0.569 & 0.581 & 0.733 & 0.657 \\
\hline Sample No. 3 & & & & & & & & \\
\hline CulDIST $_{c i}$ & $\begin{array}{c}0.294 \\
(0.184)\end{array}$ & & & & $\begin{array}{c}3.646 \\
(12.89)\end{array}$ & & & \\
\hline InstiDIST $_{c i}$ & & $\begin{array}{c}0.080 \\
(0.133)\end{array}$ & & & & $\begin{array}{c}0.207 \\
(0.276)\end{array}$ & & \\
\hline IndusDIST $_{c i}$ & & & $\begin{array}{c}-0.468 * * \\
(0.230)\end{array}$ & & & & $\begin{array}{l}-0.340 \\
(0.382)\end{array}$ & \\
\hline$E d u D I S T_{c i}$ & & & & $\begin{array}{c}-0.403 * * * \\
(0.297)\end{array}$ & & & & $\begin{array}{c}-0.462 * * \\
(0.272)\end{array}$ \\
\hline Observations & 791 & 834 & 757 & 780 & 790 & 834 & 757 & 780 \\
\hline Adjusted- $\mathrm{R}^{2}$ & 0.317 & 0.333 & 0.421 & 0.401 & 0.627 & 0.636 & 0.731 & 0.696 \\
\hline Sample No. 4 & & & & & & & & \\
\hline CulDIST $_{\text {cit }}$ & $\begin{array}{c}0.351 * * * \\
(0.126)\end{array}$ & & & & $\begin{array}{c}10.720 * * \\
(6.067)\end{array}$ & & & \\
\hline InstiDIST $_{\text {cit }}$ & & $\begin{array}{c}0.043 \\
(0.097)\end{array}$ & & & & $\begin{array}{c}-0.479 * * \\
(0.219)\end{array}$ & & \\
\hline IndusDIST $_{\text {cit }}$ & & & $\begin{array}{c}0.134 \\
(0.173)\end{array}$ & & & & $\begin{array}{c}0.405 \\
(0.293)\end{array}$ & \\
\hline$E d u D I S T_{c i t}$ & & & & $\begin{array}{l}-0.218 \\
(0.258)\end{array}$ & & & & $\begin{array}{l}-0.157 \\
(0.305)\end{array}$ \\
\hline Observations & 975 & 1,024 & 902 & 938 & 975 & 1,024 & 902 & 938 \\
\hline Adjusted- $\mathrm{R}^{2}$ & 0.292 & 0.296 & 0.405 & 0.354 & 0.542 & 0.561 & 0.692 & 0.628 \\
\hline Country-fixed & No & No & No & No & Yes & Yes & Yes & Yes \\
\hline Year-fixed & No & No & No & No & Yes & Yes & Yes & Yes \\
\hline
\end{tabular}

Note. Robust standard errors in parentheses. * Significant at $10 \%, * *$ Significant at 5\%, *** Significant at $1 \%$.

As regards vegetable products (Sample No. 2) and animal or vegetable fats and oils (Sample No. 3), distance in education and industrial development works more like measures of "psychic distance", rather than of an advantage. A larger difference between levels of education or industrial development, ceteris paribus, implies higher trade barriers between China and its trading partners, thus impeding China's exports (although the results for industrial distance are not statistically significant in the country- and year-fixed specification). Comparing the two types of distance, the distance in education has a much larger negative influence on vegetable products (Sample No. 2) than on animal or vegetable fats and oils (Sample No. 3), and the distance in industrial development has a larger effect on the latter.

\subsection{Robustness Tests with Quality Effects}

In this subsection, the quality or level of institution, education, and industrial development of both China and its trading partners are considered. The purpose is to test the robustness of (parts of) the results in the above subsections. Previous studies have found that a higher level of institutional quality, education or industrial development of either exporting or importing country may indicate a lower transaction costs (Álvarez, Barbero, Rodríguez-Pose, \& Zofío, 2018), and a comparative advantage (or disadvantage) (Dow \& Karunaratna, 2006; Belloc, 2006). As aforementioned, in our sample, a larger intangible distance may be correlated with a higher level of development of China's trading partners, and thus, adding the quality or level of institution, education, and industrial development into regressions helps to distinguish between "quality/level effects" and "distance effects", and to investigate the effects of "distance" more comprehensively and precisely (Note 4). The following model specification is estimated in this subsection: 


$$
\begin{gathered}
\ln \left(X_{c i t}+1\right)=\alpha_{0}+\beta_{1} \ln \left(G D P_{c t} * G D P_{i t}\right)+\beta_{2} \text { ComLang }_{c i}+\beta_{3} \text { Contig }_{c i}+\beta_{4} \operatorname{lnDIST}_{c i}+\beta_{5} F_{T A} A_{c i t}+ \\
\gamma_{e} \text { IntangDIST }_{\text {cite }}+\delta_{c e} \text { IntangLEVEl }_{c t e}+\delta_{i e} \text { IntangLEVEl }_{i t e}+u_{i t}
\end{gathered}
$$

where $G D P_{c t} * G D P_{i t}$ is the product of GDP of China and country $i$ (Note 5). IntangLEVEl $l_{c t e}$ and IntangLEVEl $l_{\text {ite }}$ denote the level of the eth quality of China and country $i$, respectively (Note 6).

Table 7 shows the results obtained by estimating equation (4). The directions and significance of most coefficient values are consistent with those in Table 5. As found in section 4.2, for the sample of total agro-food exports, institutional distance is the only intangible distance affecting exports significantly and negatively. Moreover, the institutional quality of China and the importing country affect China's agro-food exports significantly. An increase in the institutional quality of the importing country increases China's exports, and hence the coefficient of institutional distance is larger than that in Table 5 (Column (3)). This suggests that the effects of institutional distance is underestimated without distinguishing the "quality effects" from "distance effects", and that when the institutional distance increases in favor of the importing countries, the negative effects can be partly alleviated by the importers' improved institutional quality.

China's improvement in institutional quality and industrial development significantly decreases China's agro-food exports. This seems to differ from the results of previous studies, which found that an improvement in the level of institution or industrial development of a country helps to lower trade costs, thus, boosts exports. A possible explanation for our results is the relationship between institution or industrial development and the export structure. An improved institutional quality changes the relative transaction costs between agro-food and non-agricultural exports, and a rise in industrialization indicates a change in capital-labor endowment ratio (Dow \& Karunaratna, 2006), and both changes lead to a smaller proportion or even smaller amount of agro-food products in China's exports. While for the importing countries, a higher level of industrial development may imply a smaller demand for China's agro-food imports.

\begin{tabular}{|c|c|c|c|}
\hline Variable & $(1)$ & (2) & (3) \\
\hline \multirow[t]{2}{*}{$\operatorname{Ln}\left(G D P_{i t}{ }^{*} G D P_{c t}\right)$} & $0.944 * * *$ & $1.016^{* * *}$ & $0.857 * * *$ \\
\hline & $(0.042)$ & $(0.065)$ & $(0.066)$ \\
\hline \multirow[t]{2}{*}{ Contig $_{c i i}$} & 0.392 & 0.205 & -0.002 \\
\hline & $(0.564)$ & $(0.517)$ & $(0.497)$ \\
\hline \multirow[t]{2}{*}{ ComLang $_{c}$} & $1.959 * *$ & $2.389 * * *$ & $2.198 * * *$ \\
\hline & $(0.282)$ & $(0.806)$ & $(0.794)$ \\
\hline \multirow[t]{2}{*}{$\ln D I S T_{c i}$} & $-0.994 * * *$ & $-0.983^{* * *}$ & $-1.088^{* * * *}$ \\
\hline & $(0.294)$ & $(0.270)$ & $(0.265)$ \\
\hline \multirow[t]{2}{*}{$F T A_{\text {cit }}$} & $0.256^{* * *}$ & $0.353^{* * *}$ & $0.295^{* * *}$ \\
\hline & $(0.149)$ & $(0.145)$ & $(0.092)$ \\
\hline \multirow[t]{2}{*}{ InstiDIST $_{\text {cit }}$} & $-0.307 * * *$ & & \\
\hline & $(0.075)$ & & \\
\hline \multirow[t]{2}{*}{ InstiLEVEL $_{i t}$} & $0.447 * * *$ & & \\
\hline & $(0.135)$ & & \\
\hline \multirow[t]{2}{*}{ InstiLEVEL $L_{c t}$} & $-0.207 * * *$ & & \\
\hline & $(0.050)$ & & \\
\hline \multirow[t]{2}{*}{ IndusDIST $_{\text {cit }}$} & & 0.019 & \\
\hline & & $(0.107)$ & \\
\hline \multirow[t]{2}{*}{$I^{\prime n d u s L E V E L_{i t}}$} & & $-0.157 * *$ & \\
\hline & & $(0.103)$ & \\
\hline \multirow[t]{2}{*}{ IndusLEVEL $L_{c t}$} & & $-0.053 * *$ & \\
\hline & & $(0.029)$ & \\
\hline \multirow[t]{2}{*}{$E d u D I S T_{\text {cit }}$} & & & -0.073 \\
\hline & & & $(0.115)$ \\
\hline \multirow[t]{2}{*}{$E d u L E V E L_{i t}$} & & & 0.049 \\
\hline & & & $(0.060)$ \\
\hline \multirow[t]{2}{*}{$E d u L E V E L_{c t}$} & & & 0.044 \\
\hline & & & $(0.041)$ \\
\hline \multirow[t]{2}{*}{ Constant } & $-25.99 * * *$ & $-30.51 * * *$ & $-20.58 * * *$ \\
\hline & $(3.630)$ & (4.537) & $(4.597)$ \\
\hline Observations & 1,092 & 936 & 989 \\
\hline Adjusted $\mathrm{R}^{2}$ & 0.641 & 0.700 & 0.749 \\
\hline
\end{tabular}

Table 7. Estimation results with quality effects for total agro-food exports

Note. Robust standard errors in parentheses. * Significant at $10 \%, * *$ significant at $5 \%$, *** significant at $1 \%$. 
The results in Table 8 demonstrate that most of the effects of Tables 6 and Table 7 are robust. The results of all the samples are consistent with those in Table 6 that negative impacts of China's level of institution and industrial development are found on its agro-food exports. Both have the largest effects on food, beverages, spirits and vinegar and tobacco (Sample No.4). Surprisingly, significant negative relationships are found between China's education level and agro-food exports in all of the four samples, while they are not found in the sample of the total agro-food exports. This may be due to the fact that the individual samples do not contain zero trade values, i.e., only the intensive margin is considered for individual samples. Results in Table 8 imply that for commodities that China has already been trading with importing countries, the increase in China's level of education reduces China's exports to these countries. Few studies have discussed about the effects of a nation's educational level on cross-border trade. According to Gruber, Mehta, and Vernon (1967) and Dow and Karunaratna (2006), a country's educational level is related to human capital resources, and should be positively associated with exports of knowledge intensive products and thus may lead to an improved trade structure. This may help to explain why a higher level of China's education reduces its agro-food exports.

\section{Concluding Remarks}

The effects of intangible distance on international trade have attracted much attention, whereas the literature has somewhat ignored the effects on the agro-food industry. With an extended gravity model, this study investigates how certain dimensions of intangible distance - distance in culture, institution, education, and industrial development between China and its trading partners - affect China's agro-food exports. In addition to the sample of the total agro-food exports, a sample in each of the four categories of agro-food products are also considered to explore whether the same dimensions of intangible distance have different effects on different categories. Moreover, we control the effects of the quality/level of institution, education, and industrial development of both China and its trading partners to test the robustness of the results, and to explore the influence of "level" or "quality" on agro-food exports.

The results indicate that the distance in culture, institution, education, and industrial development are important elements in explaining China's agro-food exports, at least for certain categories of agro-food products. A larger institutional distance implies a lower volume of agro-food exports from China to its export destinations. Similarly, distance in education and industrial development hinder (certain categories of) agro-food exports, implying that China's agro-food products are more likely to be exported to countries with educational and industrial levels similar to those of China. The implication for policymakers is that a way to facilitate exports in the agro-food sector is to enhance the build-up of communication and trust with trading partners. Furthermore, increasing the institutional, educational, and industrial level may promote China's agro-food exports to more developed countries.

The effect of cultural distance is in the opposite direction. For some categories of agro-food products, exports from China are more likely to happen between China and countries with a larger cultural distance. This seems counter-intuitive, since most of the literature considers cultural distance as a measure of trade costs. In fact, when analyzing cross-border economic behaviors, cultural distance is frequently used as a national comparative advantage, thus, a larger cultural distance may imply a greater comparative advantage for the exporting country or industry.

Our results imply that China's higher institutional, industrial and educational level reduces its agro-food exports. This may be due to the products we focus on. A higher institutional, industrial or educational level of China may imply a smaller proportion of agro-food products in the total exports, or even a smaller amount of agro-food exports, i.e., the institutional, industrial level are closely correlated to the improvement of the trade structure. On the other hand, when the distance in institution, education or industrial development increases in favor of the importing countries, the negative impacts of intangible distance on China's exports are partly neutralized by the importers' improved level of institution, education or industrialization.

\section{Acknowledgements}

The author is thankful for helpful comments received at the 2018 Zhongshan International Forum. This work was supported by the Shandong Provincial University Scientific Research Project [grant number J18A185].

\section{References}

Alfnes, F. (2004), Stated preferences for imported and hormone-treated beef: Application of a mixed logit model. European Review of Agricultural Economics, 31(1), 19-37. https://doi.org/10.1093/erae/31.1.19

Alnohair, S. (2014). Obesity in gulf countries. International Journal of Health Sciences, 8(1), 79.

Álvarez, I. C., Barbero, J., Rodríguez-Pose, A., \& Zofío, J. L. (2018). Does institutional quality matter for trade? 
Institutional conditions in a sectoral trade framework. World Development, 103, 72-87. https://doi.org/10.1016/j.worlddev.2017.10.010

Álvarez, I. C., Barbero, J., Rodríguez-Pose, A., \& Zofío, J. L. (2018). Does institutional quality matter for trade? Institutional conditions in a sectoral trade framework. World Development, 103, 72-87. https://doi.org/10.1016/j.worlddev.2017.10.010

Alvarez, S. E. (2018). Cultures of politics/politics of cultures: Revisioning Latin American social movements. London: Routledge.

Anderson, J. E., \& Van Wincoop, E. (2003). Gravity with gravitas: a solution to the border puzzle. American Economic Review, 93(1), 170-192. https://doi.org/10.1257/000282803321455214

Baier, S. L., \& Bergstrand, J. H. (2002). On the endogeneity of international trade flows and free trade agreements. Retrieved from https://www3.nd.edu/ jbergstr/Working_Papers/EndogeneityAug2002.pdf

Beckerman, W. (1956). Distance and the pattern of intra-European trade. The Review of Economics and Statistics, 38(1), 31-40. Retrieved from https://discovery.ucl.ac.uk/id/eprint/17858/1/17858.pdf

Belloc, M. (2006). Institutions and international trade: A reconsideration of comparative advantage. Journal of Economic Surveys, 20(1), 3-26. https://doi.org/10.1111/j.0950-0804.2006.00274.x

Benito, G. R., \& Gripsrud, G. (1992). The expansion of foreign direct investments: Discrete rational location choices or a cultural learning process?. Journal of International Business Studies, 23(3), 461-476. https://doi.org/10.1057/palgrave.jibs.8490275

Blomkvist, K., \& Drogendijk, R. (2013). The impact of psychic distance on Chinese outward foreign direct investments. Management International Review, 53(5), 659-686. https://doi.org/10.1057/9781137277473_7

Bojnec, Š., Fertő, I., \& Fogarasi, J. (2014). Quality of institutions and the BRIC countries agro-food exports. China Agricultural Economic Review, 6(3), 379-394. https://doi.org/10.1108/CAER-02-2013-0034

Bureau, J., Marette, S., \& Schiavina, A. (2000). Non-tariff trade barriers and consumers' information: The case of the eu-us trade dispute over beef. European Review of Agricultural Economics, 25(4), 437-62. https://doi.org/10.1093/erae/25.4.437

Carrere, C. (2006). Revisiting the effects of regional trade agreements on trade flows with proper specification of the gravity model. European Economic Review, 50(2), 223-247. https://doi.org/10.1016/j.euroecorev.2004.06.001

Chaney, T. (2018). The gravity equation in international trade: An explanation. Journal of Political Economy, 126(1), 150-177. https://doi.org/10.1086/694292

Clark, T., \& Pugh, D. S. (2001). Foreign country priorities in the internationalization process: A measure and an exploratory test on British firms. International Business Review, 10(3), 285-303. https://doi.org/10.1016/S0969-5931(01)00017-8

Disdier, A., \& Head, K. (2008). The puzzling persistence of the distance effect on bilateral trade. The Review of Economics and Statisticst, 90(1), 37-48. https://doi.org/10.1162/rest.90.1.37

Dow, D., \& Karunaratna, A. (2006). Developing a multidimensional instrument to measure psychic distance $\begin{array}{lllll}\text { stimuli. Journal of International Business } & \text { Studies, }\end{array}$ https://doi.org/10.1057/palgrave.jibs.8400221

Egger, P. (2000). A note on the proper econometric specification of the gravity Equation. Economic Letters, 66, 25-31. https://doi.org/10.1016/S0165-1765(99)00183-4

Egger, P. H., \& Lassmann, A. (2015). The causal impact of common native language on international trade: Evidence from a spatial regression discontinuity design. The Economic Journal, 125(584), 699-745. https://doi.org/10.1111/ecoj.12253

Egger, P. H., \& Toubal, F. (2018). Native language and acquired language as determinants of product-level trade. The World Economy, 41(7), 1833-1846. https://doi.org/10.1111/twec.12647

Ghemawat, P. (2001). Distance still matters. Harvard Business Review, 79(8), 137-147.

Gruber, W., Mehta, D., \& Vernon, R. (1967). The R \& D factor in international trade and international investment of United States industries. Journal of Political Economy, 75(1), 20-37.

Håkanson, L., \& Ambos, B. (2010). The antecedents of psychic distance, Journal of International Management, 
16(3), 195-210. https://doi.org/10.1016/j.intman.2010.06.001

Hofstede G. (2010). Cultures and Organizations: Software of the Mind (3rd ed.). New York: Business Expert Press.

Hofstede, G. (1980). Culture and organizations. International Studies of Management \& Organization, 10(4), $15-41$.

Johanson, J., \& Vahlne, J. E. (1977). The internationalization process of the firm-a model of knowledge development and increasing foreign market commitments. Journal of International Business Studies, 8(1), 23-32. https://doi.org/10.1057/palgrave.jibs.8490676

Johanson, J., \& Wiedersheim-Paul, F. (1975). The internationalization of the firm-four swedish cases. Journal of Management Studies, 12(3), 305-323. https://doi.org/10.1111/j.1467-6486.1975.tb00514.x

Kogut, B., \& Singh, H. (1988). The effect of national culture on the choice of entry mode. Journal of International Business Studies, 19(3), 411-432. https://doi.org/10.1057/palgrave.jibs.8490394

Lankhuizen, M. B., De Graaff, T., \& de Groot, H. L. (2015). Product Heterogeneity, Intangible Barriers and Distance Decay: The effect of multiple dimensions of distance on trade across different product categories. Spatial Economic Analysis, 10(2), 137-159. https://doi.org/10.1080/17421772.2015.1023338

Lankhuizen, M., de Groot, H. L., \& Linders, G. J. M. (2011). The rade-off between foreign direct investments and exports: The role of multiple dimensions of distance. The World Economy, 34(8), 1395-1416. https://doi.org/10.1111/j.1467-9701.2011.01335.x

Lee, D. J. (1998). The effect of cultural distance on the relational exchange between exporters and importers: The case of Australian exporters. Journal of Global Marketing, 11(4), 7-22. https://doi.org/10.1300/J042v11n04_02

Levchenko, A. A. (2007). Institutional quality and international trade. The Review of Economic Studies, 74(3), 791-819. https://doi.org/10.1111/j.1467-937X.2007.00435.x

Lewer, J. J., \& Van den Berg, H. (2007). Religion and International Trade: Does the sharing of a religious culture facilitate the formation of trade networks?. American Journal of Economics and Sociology, 66(4), 765-794. https://doi.org/10.1111/j.1536-7150.2007.00539.x

Li, C., Luo, Y., \& De Vita, G. (2018). Institutional difference and outward FDI: Evidence from China. Empirical Economics, 1-26. https://doi.org/10.1007/s00181-018-1564-y

Linders, G. J., Slangen, A., De Groot, H. L., \& Beugelsdijk, S. (2005). Cultural and institutional determinants of bilateral trade flows. http://dx.doi.org/10.2139/ssrn.775504

Liu, A., Lu, C., \& Wang, Z. (2018). The roles of cultural and institutional distance in international trade: Evidence from China's trade with the Belt and Road countries. China Economic Review. https://doi.org/10.1016/j.chieco.2018.10.001

Overman, H. G., Redding, S. J., \& Venables, A. J. (2001). The economic geography of trade production and income: A survey of empirics. CEPR Discussion Paper No. 2978.

Palmero, A. J., Herrera, J. J. D., \& de la Fuente Sabaté, M. (2013). The role of psychic distance stimuli on the East-West FDI location structure in the EU. Evidence from Spanish MNEs. Journal of East European Management Studies, 18(1), 36-65.

Papadaki, A., \& Scott, J. A. (2002). The impact on eating habits of temporary translocation from a Mediterranean to a Northern European environment. European Journal of Clinical Nutrition, 56(5), 455. https://doi.org/10.1038/sj.ejcn.1601337

Schwartz, M., Bennett, W. R., \& Stein, S. (1995). Communication systems and techniques. Hoboken: John Wiley $\&$ Sons.

Shenkar, O. (2001). Cultural distance revisited: Towards a more rigorous conceptualization and measurement of cultural differences. Journal of International Business Studies, 32(3), 519-535. https://doi.org/10.1057/palgrave.jibs.8490982

Shinagawa, S., Ikeda, M., Nestor, P. J., Shigenobu, K., Fukuhara, R., \& Nomura, M. (2009). Characteristics of abnormal eating behaviours in frontotemporal lobar degeneration: a cross-cultural survey. Journal of Neurology, Neurosurgery \& Psychiatry, 80(12), 1413-1414. http://dx.doi.org/10.1136/jnnp.2008.165332

Sousa, C. M., \& Bradley, F. (2006). Cultural distance and psychic distance: Two peas in a pod?. Journal of 
International Marketing, 14(1), 49-70. https://doi.org/10.1509/jimk.14.1.49

Tadesse, B., \& White, R. (2010). Cultural distance as a determinant of bilateral trade flows: Do immigrants counter the effect of cultural differences?. Applied Economics Letters, 17(2), 147-152. https://doi.org/10.1080/13504850701719983

White, R., \& Tadesse, B. (2008). Cultural distance and the US immigrant-trade link. World Economy, 31(8), 1078-1096. https://doi.org/10.1111/j.1467-9701.2008.01115.x

Yotov, Y. V. (2012). A simple solution to the distance puzzle in international trade. Economics Letters, 117(3), 794-798. https://doi.org/10.1016/j.econlet.2012.08.032

Yu, J., King, K. W., \& Yoon, H. J. (2010). How much are health websites influenced by culture? Content analysis of online diet programs in the United States, the United Kingdom, and Korea. Journal of Promotion Management, 16(3), 331-359. https://doi.org/10.1080/10496490903294703

\section{Notes}

Note 1. Sample No. 1 covers HS Commodity Codes 01-05 (live animals and animal products), Sample No. 2 covers HS Commodity Codes 06-14 (vegetable products); Sample No. 3 covers HS Commodity Code 15 (animal or vegetable fats and oils and their cleavage products; prepared animal fats; animal or vegetable waxes); and, Sample No. 4 covers HS Commodity Codes 16-24 (food, beverages, spirits and vinegar and tobacco and manufactured tobacco substitutes).

Note 2. There is only one exporting country (China) in this model; thus, controlling the country-specific effects means that the country-pair specific effects are controlled as well.

Note 3. We regress on all the variables in equation (3), but Table 6 only contains the results for intangible distance; the results for other variables are available upon request.

Note 4. Because the values or levels of cultural indices are not directly associated with the level of nations' development, we do not consider them in this subsection.

Note 5. Table 4 shows that China's GDP is highly correlated with China's quality of institution, education and industrial development. Further tests find very high variance inflation factors when both China's GDP and China's level of education (or industrial development) are included. Therefore, we use $\ln \left(G D P_{c t} * G D P_{i t}\right)$ instead of $\ln G D P_{c t}$ and $\ln G D P_{i t}$ to avoid the problem of severe collinearity, then we get much lower variance inflation factors $(<2)$.

Note 6. Following Dow and Karunaratna (2006), we compute the distance of each indicator of intangible distance, and then reduce the dimensionality by using principal component analysis. Thus, the correlation between the "distance" variables and "quality/level" variables is not high for many dimensions of intangible distance. Although the correlation between institutional distance and country i's institutional quality is 0.60 , the variance inflation factor is not high $(=1.42)$ with both the two variables included in the regression. Therefore, we follow Lankhuizen et al. (2011) and regress on both "distance" variables and "quality/level "variables at the same time.

\section{Copyrights}

Copyright for this article is retained by the author(s), with first publication rights granted to the journal.

This is an open-access article distributed under the terms and conditions of the Creative Commons Attribution license (http://creativecommons.org/licenses/by/4.0/). 